\title{
Development Hazard: A Violation-based Approach to the Right to Development
}

\author{
Irene I. Hadiprayitno \\ Researcher/Lecturer, International Studies, Leiden University, the Netherlands \\ irehadi@gmail.com
}

\begin{abstract}
It is common to criticize the right to development as a confusing compilation of ideas that brings into question its progressive realisation. This article concentrates precisely on this deferring situation. However, rather than scrutinizing the reasons of failures, it aims to explore a violation-based approach to the right to development in its connection as an instrument to address development hazards. The analysis focuses on two aspects of the right to development, firstly, the entitlement to fair distribution of benefits, as the basic argument to the obligation not to cause any harm in development, and secondly, the entitlement to participation, as an instrument to prevent and combat development hazards.
\end{abstract}

\section{Keywords}

right to development - development - fair distribution of benefits - participation

The notion of "development" is supposed to imply progress in the sense of a structural improvement in people's possibilities to sustain their daily livelihoods. Indeed, it is not just economies that are to be uplifted but people themselves: as actors in their own development, with both living standards and capabilities of those living at the grassroots level would be increased as well. Nevertheless, as much as progress is expected, the inequitable distribution of costs and benefits is also accrued from development, manifested namely in forced displacement, loss of livelihoods and so forth caused by large scale 
projects, such as natural resource extraction, urban renewal or development programs, industrial parks, and infrastructure projects (such as highways, bridges, irrigation canals, and dams). The numbers of those affected are growing and we have seen a steep increase triggered by large-scale land acquisitions and leases - mainly for food, fibre, and fuel — by a myriad of private and public actors, often referred to as "land grabbing" or the "global land rush". ${ }^{1}$ This short description illustrates the downside of development: negative effects on entitlement positions of people at the grassroots, where people lose power and agency over their lives, risking the simultaneous loss of economic, social, and cultural resources, often in order to enable the provision of electricity, improved transit, mass tourism, cheap food supplies, and other benefits to industry, urban areas, and the middle class. While this is hardly a new phenomenon, the situation shows that what is done in the name of development does not automatically bring improvement of entitlements for its supposed beneficiaries. Instead, it could also victimize them.

In designing development policies, a primary concern should therefore be how to protect those affected by its consequences, and in particular, how to secure their access to decision-making on such policies and their execution. It is here attention is paid to the internationally accepted human rights standards and procedures. Such rights pertaining to each and every human being constitute a response to the necessity of protecting people against abuse of power, with which those involved in processes of development, as right holders would find protection against the negative impact of development.

One major human rights instrument that specifically deals with the issue of development is the Declaration on the Right to Development, which was adopted by the United Nations General Assembly in 1986. The Vienna Declaration, ratified at the UN World Conference on Human Rights in 1993, reaffirmed this right to development as a universal and inalienable human right, and acknowledged it as an integral part of fundamental human rights. ${ }^{2}$ In the light of 2030 Agenda for Sustainable Development, the United Nations has placed back the centrality of the Declaration on the Right to Development to inform the execution of the Agenda, especially as this rights provides the normative framework for ensuring a vital enabling environment for the full realization of the Sustainable Development Goals.

1 See: M. Kugelman, and S. L. Levenstein, eds., The Global Farms Race: Land Grabs, Agricultural Investment, and the Scramble for Food Security (Chicago: Island Press, 2013).

2 Vienna Declaration and Programme of Action, 25 June 1993, Part I, paragraph 10. 
The right to development takes its starting point in the need for consistent implementation of all human rights in all processes of development, which facilitates protection of human dignity in relation to the complex interface between development practices and human rights standards and procedures. Nevertheless, thirty years on from the Declaration, debates, controversies and scepticism $^{3}$ remain, contesting the practical application of this right. Scholarly discussions on the right to development concern mostly with normative aspects of the right, examining its legitimacy and the roles of multiple duty bearers especially in the increasingly globalized and yet fragmentized world. ${ }^{4}$ This article aims to advance the debate by introducing the concept of 'development hazard' as a new analytical tool to approach the meaning and the potential of the right to development.

Development hazards habitually occur when development policies are imposed from above, without any opportunity to participate for those affected at the grassroots. It is particularly large-scale development project that tend to entail such negative consequences for people. While other approaches to the right to development have been developed to understand its normative dimension, it is argued in this article, useful as they are, they tend to overlook the negative impacts caused by development policies and programmes, in the senses that instead of creating improvements in respect of access to resources and increasing opportunities for the rights holder in development, reality rather reflects development hazards, actually imperilling the individual considered to be the holder of a right to development.

Concentrated precisely on this deferring situation of the right to development in development processes, the analysis provided in this article is done not by scrutinizing the reasons of failures nor its normative insufficiencies; rather by exploring a violation-based approach to the right to development in its connection as an instrument to combat development hazards. For this purpose, the structure will be divided into two parts; the first part will concentrate on defining development as a hazard, while the second part will explain the aspects that enable activation of the right to development as an instrument against development hazards.

3 Arguments in favour and against the Right to Development can be seen for example in A. Lindrossm The Right to Development (Helsinski: Eric Castern Pub., 1999), 70-75.

4 A quite recent publication: UN-OHCHR. Realizing the Right to Development (Geneva: UN Publication, 2013), provides an extensive discussion about the issues and implications of the right to development. 


\subsection{Development as Economic Growth}

A limited understanding of development is to perceive it in connection to economic growth, where evidently development is seen as a sub-discipline of economics. In this respect, economic growth is used as a way of measuring the development process, with an increase of the value of production over time as its benchmark.

Contrary to this, Arturo Escobar views development as a 'historically produced discourse', and argues that perceiving development in terms of discourse maintains the focus of domination and explores the most pervasive effect of development. ${ }^{5}$ Establishing economic growth as a measurement of development is therefore historically constructed. When it comes to the development beneficiary, it practically limits its genuine meaning. There is no objection to viewing economic growth as necessary to combat poverty in developing countries and to provide greater life expectancy, healthier children, more food and clothing, ample shelter and better amenities. However, this principle of growth has forced countries to accept and implicate economic growth strategies as the basis of their approach to development. Consideration of growth, rather than people, becomes the governing priority that occupies development. Development becomes the focus of processes of domination and an extremely efficient apparatus for producing knowledge about, and the exercise of power over 'developing countries' ${ }^{6}$

While economists generally believe that growth provides the most efficient solution to alleviate domestic problems, experience reveals that growthoriented development cannot fully deliver the benefits of development equally for everyone. It cannot give the development beneficiary greater control over development unless this process is associated with deliberative actions to ensure inclusion of the development beneficiary. Moreover, growthoriented development is not likely to automatically increase the quality of life of the development beneficiary. For example, agricultural growth tends to induce commercialisation through market expansion. Such commercialisation of agricultural systems permits mega-agricultural investments to enter poor peasant economies and this may lead to increased landlessness. Those without assets and skills are unable to exploit the expanding opportunities associated with the spreading of the market system. To continue this argumentation, in

5 A. Escobar, Encountering Development: the Making and Unmaking of the Third World (New Jersey: Princenton Univ. Press, 1995), 5-6.

6 Ibid., 9 . 
the next sub-section the discussion will be followed by looking at some alternative ways of understanding development in order to grasp the essence of development hazards.

\subsection{Development as an Integral Normative Concept}

Responding to the economic growth-oriented development, Amartya Sen speaks of the deficiency of traditional development economics. As an economist himself, he does not disregard the significance of economic growth in development. However, the real limitations of economic development arise not from the choice of means to the end of economic growth, but from the insufficient recognition that economic growth is no more than a means to some other objective. Economic growth is crucial as some of the entitlements following from it can be realised only in processes of economic growth. Nevertheless, he warns of the danger of overemphasising the economic growth priority as judging advantages in terms of primary goods may lead to a partially blind morality. ${ }^{7} \mathrm{He}$ also argues that: ${ }^{8}$

Development economics was born at a time when government involvement in deliberately fostering economic growth in general, and industrialization in particular, was very rare, and when the typical rates of capital accumulation were quite low. That situation has changed in many respects, and, while that may suggest the need to emphasise different issues, it does not in any way invalidate the wisdom of the strategies then suggested.

Indeed, considering economic growth as an important part in development is unavoidable. However, as the scale of development grows bigger and the objective of growth acquires more emphasis, its negative impacts and deficiencies are more likely to reveal themselves. In this regard, it has been argued to relate development with the capability of the development beneficiary and its emphasis is particularly placed upon the individual context of the quality of life. The capability approach, as set out by Amartya Sen and Martha Nussbaum, provides an alternative to crude measures of development through indicators of growth that fail to account for how such wealth may be distributed, and also fail to adequately establish the quality of life of those for whom development initiatives are most crucial. According to this approach, development is

7 See G. A. Cohen. "Equality of What? On Welfare, Goods, and Capabilities", The Quality of Life, in eds. M. C. Nussbaum and A. Sen (New York: Oxford Univ. Press, 1993), 16.

8 A. Sen, “Development: Which Way Now?", The Economic Journal (1983): 752. 
a process of expanding the capabilities for people to be able to do what they actually do with the goods. ${ }^{9}$

Amartya Sen and Martha Nussbaum are amongst many scholars who have contributed to the normative clarification of the concept of development. For Sen and Nussbaum, the concept of development is inherently value-laden and therefore it yields criteria for what counts as good social change, and most fundamentally the achievement of a better life for human beings. ${ }^{10}$ According to both, economic growth is but a means - and sometimes not a very good means-towards development that concerns human 'well-being', 'quality of life", and 'standard of living'. Subsequently, development should be defined in relation to what humans can do and should be. Sen and Nussbaum in this respect employ the terms capability, to cover these doings and beings. They define development as the enhancement of certain human functionings and the expansion of human capabilities to so function.

Nevertheless to exercise their capabilities and expand their functions in life, one would also need access to resources based on legitimate claims. Accordingly, this is where the capabilities approach to development is closely related to the idea of human rights. Especially since the language of rights entails legal protection and can be used as a base for political actions and gives important precision and supplementation to the language of capabilities. ${ }^{11}$ The language of rights may provide a legal and political basis for clear motivations and goals in respect of a notion of development towards which the capability approach contributes. It has been clear that economic development might improve productivity and contribute to the allocation of resources for eradicating certain development problems; however without a corresponding human rights' measures for the right-holder, it is not necessarily relevant to the improvement of capabilities in life.

Clearly, this involves affirmative material and institutional support, not just the ability not to impede. Human rights entitlements cannot simply be regarded as granted once it has been incorporated in positive law. The right-holders

$9 \quad$ M. C. Nussbaum and A. Sen, The Quality, 31.

10 D. A. Crocker, "Functioning and Capability: the Foundations of Sen's and Nussbaum's Development Ethic", Political Theory 20 (1992): 585.

11 Rights have been understood in many different ways, and difficult theoretical questions are frequently obscured by the use of rights language, which can give the illusion of agreement where there is deep philosophical disagreement. People differ about what the basis of a rights claim is: rationality, sentience, and mere life have all had their defenders. The capability approach has the advantage of taking clear positions while stating clearly what the motivating concerns are and what the goal is. M. C. Nussbaum, "Capabilities as Fundamental Entitlements: Sen and Social Justice”, Feminist Economist 9 (2003): 36-37. 
enjoy the concrete entitlement only if there are effective measures to get them into a position and truly capable to exercise their rights. In this regard, one can conclude that incorporating the language of rights as an integral normative concept of development also signifies a transformative impact. The structural implementation of human rights is a necessity, and consequently there should be a corresponding system of advancing the entitlement positions of the development beneficiary as the right-holder.

Furthermore, entitlement positions concern not only the fulfilment of basic needs, rather the possibility to make legitimate access to resources and legitimate claims over goods and services. ${ }^{12}$ It corresponds to the possibility to make legitimate claims and in that sense is a function of both law and power. Power means opportunity or actual command. ${ }^{13}$ Law, on the other hand, legitimises and hence protects in case of dispute. The right-holder can use human rights principles to justify their claims and be protected also in the case of dispute or conflict if their acts backfire against them.

In a situation where a large-scale development project is being implemented, this implies that the people who are affected by the project should have the power and be protected by law to secure their entitlement positions. The resettlement procedures should at least consider the entitlements people have already acquired in the area where they live or where the development project is taking place. If the situation suggests otherwise, derived from the basis of the human rights principles-particularly considering the right to development, the people should be able to lodge their complaints, seek remedies, or claim compensation. Should their entitlement positions be degraded or if there arises a situation of acquirement failures in the context of development process; one would speak of a development hazard.

\subsection{Identifying Development as a Hazard}

At this point one can conclude that development hazards take place when a development process disturbs essential entitlement positions of those involved. It happens when development negatively affects the right-holders in terms of their legitimate access to resources and their legitimate claims over goods and resources, thus inhibiting their capabilities and functionings in life.

12 B. de Gaay Fortman, "Beyond Income Distribution: An Entitlement Systems Approach to the Acquirement Problem," in The Economics of Income Distribution: Heterodox Approaches, eds. J. van der Linden et al. (Brookfield: Edward Elgar, 1999), 42.

13 B. de Gaay Fortman, "In Search of a New Paradigm: Development Interventionism from a Human Dignity Perspective”, in The Development of Religion, the Religion of Development, eds. O. Salemink et al. (Delft: Eburon, 2004), 27. 
A major cause of development hazards is the perspective adopted in development policies, when material priorities, i.e. productivity and growth, fully dominate human conditions. Firstly, this corresponds to the failure to recognise human rights aspects in development, for example in the case of displacement, where resettlement should be provided in accordance with the basic rights of the victims. Secondly, this has something to do with the perception of unjust practices or the ability of the right-holder to discern the potential to obtain justice in a hazardous situation. What the right-holder refers to as justice depends on the basic interest and entitlement positions to such an extent that they ought to be enforced by the corresponding entitlement arrangements. ${ }^{14}$

Identifying the faces of development hazards requires a combined approach by the state-arranged entitlement systems, institution-based entitlement strategies, and private law (property law, contract etc.). ${ }^{15}$ Here one is examining a mal-functioning economy, bad government and serious socio-cultural constraints. The faces of development hazards take place when actual acquirement systems, which manifested in both activities and honoured claims in the context of the state-arranged entitlement systems, institution-based entitlement strategies, and private law, are failing to respect, protect and fulfil the entitlement positions of the right-holders.

One of the best studied faces of development hazards is displacement, which occurs because of the implementation of mega development projects, or as pointed out earlier the dams and urban transportations. Michael Cernea, a former advisor of the World Bank, points out that: ${ }^{16}$

The worst consequences of forced displacement occur in domestic projects that are not guided by national or international policy norms. Our study found that impoverishment and brutal violations of basic human rights happen most frequently in programmes that are not subject to agreement on policy guidelines and to professional outside review, supervision and evaluation.

Stated differently, in the cases of displacement, there occur failures of existing entitlement systems occur in compensating the negatively affected entitlement positions as caused by development projects. In that respect, the State

14 Here reference is made to what was earlier referred to as the state-arranged entitlement, the institution-arranged entitlement, and the private law protection.

15 B. de Gaay Fortman, "In Search of", 19-29.

16 M. Cernea, "Understanding and Preventing Impoverishment from Displacement: Reflection on the State of Knowledge", Journal of Refugee Studies 8 (1995): 251. 
appears to play a pivotal role in the whole process. Such failed projects present a dysfunctional combination of the stated arranged entitlement systems, the institutional based strategies, and the private law, all aspects that requires an active role from the State. In the phenomenon of displacement, the State fails thus in providing the adequate resettlement to prevent impoverishment, the law fails in enforcing the agreement or contract, and there is no community or association which can secure compensatory entitlement.

Moreover, impoverishment does not merely take place in the form of displacement; it can also include the degradation of standards of living resulting from a lower income, vulnerability to morbidity, dispossession of houses and the like. Another face of development hazards manifests itself when a society, after the implementation of a development project, becomes vulnerable to social conflict.

In such situations participation is, therefore, an acute necessity and serves as a preventive or a remedy to combat development hazards. In an ideal state, of course, participation is protected by providing the channels consultation as well as the systems for remedies, compensation and proper resettlement. When hazards are occurred victims can perform combating actions through the judicial political activism based on law.

\section{The Right to Development as an Instrument against Development Hazards}

The aim of the right to development is to establish development as a human rights concern, which is a controversial subject as this means bringing moral dimensions to the development debate. In fact, it leads to a vision of what ought to be, contesting this with what is lacking. This is tricky business, as it involves contradictory rationale between the distinct domains of human rights and development. Development theories do not have the same basis as human rights. They originated from the work of economists, while focusing on the State and macroeconomic phenomena. The social aspects were secondary to the goal of economic growth and transformation and were used as a means to ensure a more effective use of resources instead of a goal. ${ }^{17}$ Human rights on the other hand are concerned with the protection of people's actual freedoms and entitlements.

17 H. Otto Sano, "Development and Human Rights: The Necessary, but Partial Integration of Human Rights and Development", Human Rights Quarterly 3 (2000): 739. 
Particularly for developing countries, this is not a simple matter. There is a contradictory precedence transpiring between development and human rights. Developing countries often focus their development agenda on accelerating their economy, by providing an enabling environment to be conducive to investments and growth, while neglecting people's freedoms and entitlements. It becomes complicated for developing countries as their development agenda is usually confronted with, for example, poverty problems that already impair the capabilities of the development 'beneficiaries' in their social, political and cultural life.

It is inevitably, therefore, that for developing countries the right to development means the right to expand their economies rapidly, irrespective of environmental and social costs. In the sense then, the right to development becomes simply a right of states to pollute rivers, displace people, and create development refugees. For developed countries, the right to development is simply not a 'right', but only a goal or a claim - that is it is not an entitlement that can be enforced in courts by individuals. Subsequently, the implementation of the right to development has been merely revolved around establishing a dialog-based approach in development processes. The development compact as a model to implement to right to development suggested by the Independent Expert, Arjun Sengupta, in 2002 exemplifies the current trend of the right to development. ${ }^{18}$ As merely a framework for a dialog, the right to development has been put into a theoretical and political debate without any concrete proposals that are actually significant for those being victimized by development processes.

In this vein, it remained necessary to clarify the meaning and the potentiality of the right to development. In particular it is necessary to establish a violation-based approach to the right to development. Therefore the right could be implemented as an actual entitlement of the right-holders in development processes. For this purpose, the following sections will discuss the content of the right to development relevant to establishing development hazards as violations of human rights, the issues of the right-holder, the state obligations and participation as method to combat development hazards.

\subsection{Fair Distribution of Benefits and Development Hazards}

Article 1(1) of the Declaration on the Right to Development defines the right to development as an inalienable human right by virtue of which every human person and all peoples are entitled to participate in, contribute to, and enjoy

18 E/CN.4/2002/WG.18/2, Fourth report of the independent expert on the right to development, Section III.B on Development Compacts. 
economic, social, cultural and political development, in which all human rights and fundamental freedoms can be fully realised. Based on this definition, the right to development suggests two entitlements in the development process; a substantial entitlement, in relation to the fair distribution of development benefits, and a procedural entitlement, which is related to the involvement of the right-holder in the development process.

The entitlement to fair distribution of development benefits is recognised in Article 8(1) of the Declaration on the Right to Development. This article evokes the entitlement of the right-holder in terms of access to basic resources, education, health service, food, housing, employment and the fair distribution of income. In a similar vein, Article 2(3) also highlights the obligation of the State to formulate appropriate national development policies that aim at the fair distribution of the benefits resulting from development.

The entitlement to fair distribution of benefits was again reaffirmed in the Vienna Declaration. Paragraph 11 of the Vienna Declaration extends the notion of equitable access to the benefits of development to embrace the notion of intergenerational equity ${ }^{19}$ It states that, "the right to development should be fulfilled so as to meet equitably the developmental and environmental needs of present and future generations. ${ }^{20}$ Such developmental needs, quoting from the UNGA Resolution on the World Social Situation, ${ }^{21}$ include for example employment, education, health, nutrition, housing facilities, crime prevention and the wellbeing of children.

Fairness in distribution of benefits for the development beneficiary implies that development policies ought to be impartially designed to serve and to be favourable for everyone. As it has been argued above, development used to be identified with economic indicators, which revolved around accelerating growth. However, this precedence does not always have an auspicious effect for the entire population. Some might benefit more than others. Hence, a provision on fair distribution of benefits is a valuable instrument to address such problems in the development process. It entails viewing development's benefits as an entitlement of the entire population to improve their well-being. ${ }^{22}$

19 A. Orford, "Globalisation and the Right to Development", in Peoples Rights, ed. P. Alston (Oxford: Oxford Univ. Press, 2001), 140.

$20 \quad$ Vienna Declaration and Programme of Action, 11.

$21 \mathrm{~A} / \mathrm{RES} / 45 / 87$, World Social Situation. This resolution was adopted by 146 to 1 (USA) with 4 abstentions (FRG, Israel, Japan, and UK).

22 The concept of 'wellbeing' in this context extends beyond the conventional notions of economic growth. It includes the expansion of opportunities and capabilities to enjoy those 
The entitlement to fair distribution of benefits is a distinct character of the right to development that differentiates it with other economic, social and cultural rights. Those set of rights stipulate entitlements that are necessary for indicating progress in development, such us fulfillment of the right to food, protection of the right to work and so forth. However, they do not specifically address the situations where misinterpreted development processes are taking place. In which rather than creating structural progress, people are become victims of development. The entitlement to fair distribution of benefits suggests that there have to be beneficial effects in development processes and they will be distributed fairly among development beneficiaries. That calls for a mutually advantageous relationship between the developers (the state or other development agents) and the beneficiaries. Therefore, harmful activities should be structured so that those who reap the benefits must bear the burdens. It is exactly why the right to development may be employed as an instrument against development hazards.

To draw the faces of development hazards, it is necessary to link the above argument with the idea of the vector approach right to development. The independent expert describes the vector approach because the realisation of the right to development requires an improvement of this vector, such that there is improvement of some, or at least one, of those rights without violating any other. ${ }^{23}$ Furthermore, the Independent Expert proposes the right to food, the right to primary education and the right to primary health as the three rights vital to practically implement the right to development.

These three rights have been chosen because they are closely related to the right to life- the most basic of all human rights. Food is essential for survival; primary health care is indispensable as a minimum requirement for living without illness, at least in the early years; and primary education is necessary for the mental development of a young person to be able to grow up as a full individual. The choice has also been influenced by the fact that several international organisations have been working in

opportunities. See A. Sengupta, "On Theory and Practice of the Right to Development", Human Rights Quarterly 24 (2002): 848.

23 The name of umbrella of rights or synthesis of rights represent the argument on the originality of the right to development as a synthesis of rights, which thus is not considered valuable contribution to the existed sets of rights. E/CN.4/2002/WG.18/6, Fifth Report of the Independent Expert on the Right to Development, Paragraph 6. 
these areas with action plans which may be more easily built up into a feasible, global human rights programme. ${ }^{24}$

In this light of all the above, particularly considering that hazards manifest themselves in the overall impoverishment processes resulting from development, reflecting the fact of losing the capital, ${ }^{25}$ dignity and capabilities, faces of development hazards include displacement and landlessness, joblessness, degradation of livelihood and health conditions that increase morbidity, and food insecurity.

Notably, displacement is the most pronounced face of development hazards caused by a large development project. It is frequently followed by homelessness and landlessness. Both refer to expropriation of lands and the removal of the main foundation upon which the right-holder relies for the productive system, commercial activities, and livelihood. This is the principal form of decapitalisation and pauperisation of the right-holder, through which they lose not only their capital, but also their capabilities.

As to joblessness, it occurs especially in urban development projects, where large development projects restructure the existing economic system, resulting in development victims among the urban population, mainly those who are already in vulnerable positions. It could also happen in rural areas, displacing landless workers and small or home businesses. Creating jobs becomes as difficult as finding new land. Unemployment is unavoidable after the physical relocation and this marginalises both the political and the economic positions of the development beneficiary.

Moreover, serious health problems, such as the outbreak of relocationrelated parasites or diseases are easily found in the phenomenon of development hazard. Vulnerability to illness is increased because of development

E/CN.4/1999/WG.18/2, First Report of the Independent Expert on the Right to Development, paragraph 34. At paragraph 35 the independent expert continues by saying that he was fully aware that several other areas of human rights could be chosen by the international community as being of equal importance. In fact, there is no way of choosing a few among them in preference to others except through discussions and deliberations in the international forums, spelling out the implications of the choice and their feasibility within the possible supply of national and international resources. The only point the independent expert would like to make is that, at least to begin with, the choice should be limited to a minimum of a few areas and to attempt to make a success of the programme, which can then be extended to other areas with equal success.

25 M. Cernea, "Understanding", 251, defines capital as natural capital, man-made capital, human capital and social capital. 
projects that condone the occurrence of livelihood deterioration, such as unsafe water supply and waste systems and these tend to spread infectious diseases, diarrhoea, or dysentery.

The last face of development hazards is food insecurity. This occurs when the people are forced to uproot their livelihood, placing them in the vulnerable position to chronic food insecurity. Not only in terms of their economic capability or income, but also in terms of the decreased level of nutrition intake that is necessary for normal growth and work.

Combating these faces of development hazards assigns in making priorities in development processes. Here, it is crucial to see these hazards as a violation of the right to development based on the non-implementation of the entitlement to fair distribution of benefits. However, one should bear in mind that implementing the right to development is more than just fulfilment of the right to food, right to education, or right to health. Therefore, in light of the right to development, fulfilment of these hazardous situations that are also related to the selected economic, social and cultural rights requires an environment where entitlements connected with civil and political rights are also guaranteed.

\subsection{The Right-Holder: State, People or the Individual?}

The first step to establish a violation-based approach to the right to development is to clarify whether this right should be identified as a people's right, a states' right or an individual's right. This question arises because the right to development implies the fulfilment of the right to self-determination, which venerates people as the right-holder. In Article 1(2), the Declaration asserts this by stating that 'the human right to development... implies the full realisation of the right of peoples to self-determination. ${ }^{26}$ The second classification occurs because the right to development enables states to address imbalance as an entitlement for the development cooperation. Article 3(3) affirms this entitlement by stating that 'states have the duty to co-operate with each other in ensuring development and eliminating obstacles to development. States should realise their rights and fulfil their duties in such a manner....". Confusion transpires since Article 2(1) of the Declaration strongly affirms that the human person is the central subject of development.

Article 1(2) of the Declaration on the Right to Development asserts the right of peoples to dispose freely of their natural resources and that in no case a people may be deprived of its means of subsistence. Nevertheless, establishing

Declaration on the Right to Development, Art. 1(2). 
people as the right-holders of human rights is not without any complication. In this regard, Donnely once argued, if the right to development is given to others, in this regard the state or the people it can be misused. ${ }^{27}$ According to the origin of the notion of people and its definition in international law related to the minority issues, establishing people as the right-holder to the right to development is considered debatable. ${ }^{28}$ Particularly, understanding the right to development as a state right will represent a radical re-conceptualisation of human rights and an especially a dangerous one as the designated right-holder could at the same time be the potential actor that infringe human rights. ${ }^{29}$ Human rights are rights that protect the individual against the State or in other words ensure that the State guarantees to each individual certain minimum goods, services and opportunities. ${ }^{30}$ Thus the motivation to establish state as the subject in the right to development would be irrelevant.

Furthermore granting the right to development to people can also lead to similar risk, interpreting it as 'the right of the states'. Examples to this are easy to be found in many Asian governments. Yash Ghai, who specifically questioned the championing of the right to development by Asian governments, says that the support of this right by those governments is part of a broader agenda of establishing the primacy of economic development over human rights. ${ }^{31}$ The promotion of this ideology justifies repression in the national domain and the evasion of responsibility abroad.

Based on this argument establishing a violation-based approach thus requires focussing specifically on the right to development in its individual dimensions. This will be done without disregarding the Global Consultation

27 J. Donnelly, "In Search of the Unicorn: the Jurisprudence and Politics of the Right to Development", California Western International Law Journal 15 (1985): 473-475.

28 There are also particular difficulties in identifying 'minorities' and 'people', see:J. Crawford, The Right of Peoples: Peoples or Governments? in The Right of Peoples, ed. J. Crawford (Oxford: Clarendon Press, 1988), 5. See also J. Rawls, The Law of Peoples (Cambridge: Havard Univ. Press., 1999), 23-25.

29 M. Bedjauoui, "The Right to Development", in International Law: Achievement and Prospect, ed. M. Bedjaoui (Dordrecht: Martinus Nijhoff, 1992), 1184.

$30 \quad$ J. Donnely, "In Search", 498.

31 Y. Ghai, "Human Rights and Governance: the Asian Value", Asian Pacific Journal on Human Rights and International Law 1 (2000): 21. 
(1990), ${ }^{32}$ the UN General Assembly resolutions ${ }^{33}$ the working groups' report, ${ }^{34}$ and the Declaration on the Right to Development, which all states individual, peoples, and States as the right-holders, This is not only to enhance its practicality and to avoid those misinterpretations that are not favourable to the right-holder, but also it is congruent with the main definition of the right to development provided in the Declaration. Article 1(1) of the Declaration on the Right to Development explicitly asserts that it 'is an inalienable human right by virtue of which every human person and all peoples are entitled...' Moreover, Article 2(1) of the Declaration also provides a stronger provision by affirming that 'the human person is the central subject of development...' Not only that, the status of the human person as the subject of the right to development has acquired similar if not stronger recognition in the UN's resolutions and reports ${ }^{35}$ and been also been emphasised in the Vienna Declaration. Particularly in the Vienna Declaration, the human being was unanimously confirmed as the central subject of development. ${ }^{36}$

Thus, the terms people and state as used in the Declaration as an environment in which individuals as right-holders are bound to advance their entitlements. Indeed, the debate about whether the right to development is an individual's or people's right is considered as being rather pointless since an individual's rights cannot be exercised in isolation from the community.

\subsection{The State Obligations}

The Declaration on the Right to Development addresses the general duty of all States, or international obligations, and states obligations. With respect to the

32 E/CN.4/199o/9/Rev.1, Report on the Global Consultation on the Realisation of the Right to Development, paragraph 147; See also R. L. Barsh, "The Right to Development as a Human Right: Result of the Global Consultation”, Human Rights Quarterly 13 (1991): 329.

33 See A/RES/48/130, The Right to Development, Preamble; A/RES/49/183, The Right to Development, paragraph 1; A/RES/50/184, The Right to Development, paragraph 1; A/ RES/52/136, The Right to Development, paragraph 1; A/RES/53/155, Study on the Current State of Progress in the Implementation of the Right to Development, paragraph 2.

E/CN.4/1993/16, Concrete proposals for the effective implementation and promotion of the Declaration on the Right to Development, Report of the Secretary-General, paragraph 15; E/ CN.4/1994/21, Report of the Working Group on the Right to Development on its first session, paragraph 35 .

35 The high level task force on the right to development also emphasises individual as the right holder in the criteria for assessing the realisation of global partnership of the right to development. E/CN.4/2005/WG.18/TF/3, Report of the high-level task force on the implementation of the right to development on its second meeting, paragraph 82 . 
first one, article 3(3) of the Declaration mentions the obligation of 'States to cooperate with each other in ensuring development and eliminating obstacles to development'. Particularly in Article 4, the Declaration proclaims that: 'States have the duty to take steps, individually and collectively, to formulate international development policies with a view to facilitating the full realisation of the right to Development'. Nevertheless as has been argued before, emphasizing the role of international obligations over the state obligation would trap the right to development into a 'state-to-state' right. Of particular concern is that such approach would inhibit implementation of the right to development as to provide justice for victims of development. Moreover, modalities to ensure that fair distribution of benefits is protected and honoured exist in domestic context, in the form of set of guaranteed entitlements in the constitutions and following regulations as well as the jurisdiction of the national court. This makes it more relevant to regard State as the primary duty-bearer.

The obligation of States toward their own population in enforcing human rights is considerably more established and encouraged than those of multinational and international organisations. The Declaration asserts the central role of state as the duty-bearer to the right to development. Article 3(1) says that: 'states have the primary responsibility for ... the realisation of the right to development'. Similarly, the African Charter on Human Rights, ${ }^{37}$ the Vienna Declaration, ${ }^{38}$ and various UN resolutions on the right to development ${ }^{39}$ also emphasise the respective role of the states as the main duty-bearer.

The Declaration mentions a range of states obligations to the right to development. They include the responsibility to create enabling environments for the right-holder to fully realise the right to development. In this regard, it is the duty of the State to formulate appropriate national development policies and to undertake all necessary measures for the realisation of the right to development and encourage popular participation. States are also obliged to remove obstacles to development resulting from failure to observe civil and political rights as well as economic, social, and cultural rights ${ }^{40}$ and to eliminate the massive and flagrant violations of the human rights affected by situations such as apartheid, racial discrimination, colonialism, foreign domination. ${ }^{41}$

African Carter of Human Rights, Article 22, stipulates that: "states shall have the duty, individually and collectively, to ensure the exercise of the right to development."

38 Vienna Declaration and Programme of Action, 10.

39 A/RES/52/136, The Right to Development, paragraphs 5 and 6; A/RES/51/99, The Right to Development, paragraphs 2, 6, and 11; A/RES/50/184, The Right to Development, Preamble.

40 Declaration on the Right to Development, art. 6(2).

41 Declaration on the Right to Development, art. 5.
} 
The report of the Intergovernmental Group of Experts on the Right to Development on the Questions for the Realisation of the Right to Development mentions that 'state responsibility for the realisation of the right to development can also be examined at three levels: the obligation to respect, the obligation to protect, and the obligation to fulfil' ${ }^{42}$ Relevant to establishing a violation-based approach to the right to development is particularly obligation to respect.

The obligation to respect requires the state, and thereby all its organs and agents, to abstain from doing anything that violates the integrity of the rightholder or infringes on his or her opportunity to exercise the right to development. Actions or policies that may contravene the obligation to respect include the adoption of laws or policies manifestly incompatible with human rights standards, or other international legal obligations, or in pre-existing domestic law, and the repeal or suspension of legislation necessary for the continued enjoyment of human rights. ${ }^{43}$

In the Declaration on the Right to Development, the obligation to respect is regulated in Article 6(1). This Article requires the State to have respect for all human rights and fundamental freedoms without any distinction as to race, sex, language or religion. ${ }^{44}$ In light of this article, the Report of the Intergovernmental Group of Experts mentions the obligation of states to take economic and social measures to avoid the exclusion of certain marginalised groups. ${ }^{45}$ In a similar vein, the Commission on Human Rights has called for a gender perspective and gender analysis in relation to the right to development. ${ }^{46}$ Similarly, in February 2002, the meeting of the Open Ended Working Group on the Right to Development (oEWG) emphasised the importance of involving women in the realisation of the right and of applying a gender perspective to the entire process. ${ }^{47}$ These international recommendations

42 E/CN.4/1998/29, Question of the Realisation of the Right to Development, Chapter 2, paragraph 66.

43 General Comment No. 14, The Right to the Highest Attainable Standard of Health, Paragraph 50; General Comment No. 12, The Right to Adequate Food, Paragraph 37; General Comment No. 18, The Right to Work, Paragraph 23; General Comment No. 13, The Right to Education, Paragraph 47.

44 Declaration on the Right to Development, Art. 6(1).

45 E/CN.4/1998/29, Question of the Realisation of the Right to Development, Chapter 2, paragraph 68.

46 E/CN.4/RES/2001/9, The Right to Development, paragraphs 14-16.

47 E/CN.4/2002/28/Rev.1, Report of the Open Ended Working Group on the Right to Development on its Third Session, paragraph 105 (b). 
advocate that States to redress the problem of inequality and discrimination in development practices.

The Intergovernmental Group of Experts on the Right to Development corresponds the obligation to respect to the right to development with the state obligation to preserve natural resources in the development process. Their report on the Question of the Realisation of the Right to Development in 1998 calls particularly for the attention of the State to respect the natural resources and their economy, based on the condition of life of the local population. ${ }^{48}$ This means that the State is obliged to respect natural economy resources, which also includes local economy interests in designing development policies that aim at improving the conditions of life. This perspective leads to the inclusion of the right-holder through participation in designing development policies that may affect or exploit natural or indigenous resources.

A specific approach on looking to the obligation to respect the right to development is to understand it as an obligation not to damage or cause harm. ${ }^{49} \mathrm{As}$ stated previously, an obligation to respect compels the State to withdraw from human rights violations. In this regard, causing harms in development processes thus means that the State is taking part in or even acting as an offender in relation to the entitlement to fair distribution of benefits.

With respect to activating the right to development to combat development hazards, State needs to assume the obligation to protect and the obligation to fulfil. The obligation to protect means not allow others to deprive the right-holder of the guaranteed right. It requires the State to take all measures, including passing and enforcing laws, to ensure that the individual under its jurisdiction are protected from infringements by third parties (individual, groups or corporations). In Article 8(1) the Declaration stipulates that the State should undertake, at the national level, all necessary measures for the realisation of the right to development. In this regard, the state is required to adequately regulate the action of other entities, preventing them from denying or limiting the enjoyment of these rights, including the entitlement to fair distribution of benefits. In this light, the obligation to protect also implies addressing any harmful practices by aggressive entities, such as powerful economic

48 E/CN.4/1998/29, Question of the Realisation of the Right to Development, Chapter 2, paragraph 69 .

49 D. Beetham, “The Right to Development and Its Corresponding Obligation", in Development as a Human Right: Legal, Political and Economic Dimension, eds. In B. A. Adreassen et al. (Cambridge: Harvard School of Public Health, 2006), 84-85. 
interests. ${ }^{50}$ Particularly with regard to natural resources, the obligation to protect compels the State to protect the economic basis and conditions of life of the local population. ${ }^{51}$

The obligation to fulfil compels the duty-bearer to work actively to establish political, economic, and social systems and infrastructures to provide access to the right in question. This duty requires the State to proactively realise the rights of everyone by way of facilitation or direct provisions. For example, the State has the obligation to see that actions to adopt reforms to combat poverty are implemented and effective. The State also has the duty to oversee private institutions or companies that provide basic infrastructure throughout the country and to ensure that their services are adequate and appropriate according to the human rights standard committed by the country.

\subsection{Combating Development Hazards by Means of Participation}

The procedural aspect of the right to development aims at the inclusion of the right-holder in the development process. The Declaration suggests two approaches to look at participation. The first approach perceives participation as an entitlement that depends on the initiation of the state. The Article 2(3) of the Declaration on the Right to Development ${ }^{52}$ stipulates that a development policy should be designed through a process of participation and that the State has the duty to provide the appropriate policies that enable people to participate. Another approach of looking at participation according to the Declaration on the Right to Development is coming from the right-holders perspectives. The term 'popular participation' stated in Article $8(2)^{53}$ addresses a different approach of looking at a participatory process. An early document adopted by the United Nations defines popular participation as "closest to the ideal mode of participation as it reflects voluntary and autonomous action

50 A.Eide et al, The Right to Development and Human Rights in Development: A Background Paper, Prepared for the Nobel Symposium organised in Oslo from 13-15 October 2003, 16.

$5^{1}$ E/CN.4/1998/29, Question of the Realisation of the Right to Development, Chapter 2, paragraph 69.

$5^{2}$ Declaration on the Right to Development, Article 2(3) states that "States have the right and the duty to formulate appropriate national development policies that aim at the constant improvement of the wellbeing of the entire population and of all individuals, on the basis of their active, free and meaningful participation in development and in the fair distribution of the benefits resulting thereof".

53 Declaration on the Right to Development, Article 8(2) states that "States should encourage popular participation in all spheres as an important factor in development and in the full realization of all human rights". 
on the part of the people to organise and deal with their problem unaided by government or other external agencies". ${ }^{4}$ The African Charter on Popular Participation in Development and Transformation defines the term 'popular' as the role of the people and their popular organisations to be fully involved, committed and must, indeed, seize the initiative in development processes. ${ }^{55}$ Notably, the term 'popular participation' implies the necessity of an enabling environment to facilitate initiatives from the right-holders themselves. Both articles show strong emphasis in participation as a principle to implement the right to development. The right to development entails an entitlement to be consulted and to be involved in the formulation of development policies. In fact, participation is the cross-cutting principle in the right to development and enables it to be characterised as a 'participatory right'. 56

The approaches to the entitlement to participate require the State to take concrete steps that ensure the existence of an enabling environment. The Declaration clarifies the obligation of the State to include eliminating human rights violations that are obstacles to the right to development ${ }^{57}$ and ensuring the full exercise and progressive enhancement of the right to development including the formulation, adoption and implementation of a policy, legislative and other measures. ${ }^{58}$ In this respect, the Report of the Global Consultation mentions some actions that can facilitate participation, which include the representation in and the accountability of decision-making bodies, public access to information and responsiveness of decision makers to public opinion. ${ }^{59}$

The Report of the Global Consultation emphasises that participation as a tool to implement the right to development must be active and must involve genuine power. This entails the entitlement to make decisions collectively and to choose their own representative organisations and to have freedom of democratic action, free from interference. ${ }^{60}$ Furthermore, the Global Consultation asserted that participation is 'effective in mobilising human and natural

54 United Nations, Popular Participation as a Strategy for Promoting Community Level Action and National Development (1981), 8.

African Charter on Popular Participation in Development and Transformation, Paragraph 14, Chapter II.

$56 \quad$ K. Ginther, "Participation and Accountability: Two Aspect of the Internal and International Dimension of the Right to Development", Third World Legal Studies (1992): 55-57.

Declaration on the Right to Development, art. 5 .

58 Declaration on the Right to Development, art. 10.

59 E/CN.4/1990/9/Rev.1, Global Consultation on the Right to Development, paragraph 178.

$60 \quad$ Ibid., 147 . 
resources and combating inequalities, discrimination, poverty and exclusion, ${ }^{61}$ which implies viewing participation both as a mean to an end and as an end itself. ${ }^{62}$ The report also pointed out that effectiveness of participation had to be assessed from a subjective perspective; based on the opinion of the affected persons. ${ }^{63}$

A rationale for participation according to the report is that development beneficiaries should not be considered as simply "resources" to be made healthy, skilled, and productive. Rather they have a right not only to survival and material improvement, but also to some measure of power. ${ }^{64}$ With regard to the function of participation against the phenomenon of development hazards, the Report implicitly addressed this by considering participation as an effective mechanism to combat inequalities, discrimination, poverty and exclusion.

At the national level, the freedom and entitlement to participate should be honoured as a right guaranteed by the national legislation, granting it not only in the civil and political arena, but also in economic, social and cultural life. ${ }^{65}$ This entails ensuring the access to participate in the decision making of development policies, securing the entitlement of right-holders, not only to prevent injustice resulting from development policies, but also to seek remedies if such injustice occurs. In this regard, participation is taking the form of a political action in addressing injustice of development processes, which could add or replace the possibility of a legal action. Ultimately, the objective of the principle of participation is to add value to development processes at the national level. Development is not merely about improving living conditions but more importantly it is about advancing the positions of the rightholders. An active involvement of the right-holders represents their political or leverage positions.

From this perspective, one might conclude that the right to development attaches a new consequence to the discourse on human rights, particularly with regard to the implementation of the economic, social and cultural rights. While economic, social, and cultural, rights require the process of promoting and protecting the availability of and access to resources, participation

\footnotetext{
$61 \quad$ Ibid., 150.

62 Ibid., 149 .

63 R. Malhotra, Towards Implementing the Right to Development; A Framework for Indicators and Monitoring Methods, Development as a Human Right, Legal, Political and Economic Dimensions 201 (2006).

64 R. L. Barsh, "The Right", 330.

65 E/CN.4/1994/21, Question of the Realisation of the Right to Development, Paragraph 43.
} 
according to the right to development enriches that process with the entitlement to be consulted and involved in the decision making policies towards the realisation of this set of rights. For example, realising the right to development in relation to the right to food will not only require a state obligation to the availability of food resources, but also the opportunity and access of the rightholder to participate in the state's decision making on food policy. Similarly, for health issues the right to development introduces the involvement of the rights holder in the formation of health policies.

In this regard, the entitlement to participation of the right to development possesses a transformational value for the right-holders. Their ultimate aim in development process is not merely to fulfil of material needs, but the right to development also empowers them to politically address the injustice occurred in development processes. In effect, as the political action is coming from the side of the right-holders, this will help to expose more human rights violations and add to the efforts of promoting human rights in general.

The above argumentation reveals that the entitlement to participation strengthens the position of the beneficiaries both economically and politically and at the wider domain breeds sustained improvement of the well-being of the entire population. ${ }^{66}$ As a result, not only the continuity of the project is ensured but also the effectiveness of development projects and programmes is guaranteed. Particularly in respect of the phenomenon of development hazards, participation may deliver a remedial effect for the victims to seek compensation and retribution. Through exercising participation, right-holders are actively concerned about the adverse situation and are taking actions to reclaim their entitlement positions. Based on this perspective, participation may have preventive and remedial functions in combating the phenomenon of development hazards.

\subsubsection{Preventive Function}

The preventive function of the entitlement to participation is fulfilled when the exercise of the entitlement to participation successfully avoids development beneficiaries from becoming the victims of development policies, programmes and projects.

One of the most remarkable cases that demonstrate the potential of participation as having a preventive function is observed in case of the Philippines in the UN reporting system procedure. During the tenth session of the Committee on Economic, Social and Cultural Rights, certain csos drew the attention of the Committee to several matters that are related to the forced eviction of

66 A. Sengupta, "On Theory", 848. 
large numbers of families. ${ }^{67}$ In response to that call the Committee asserts the necessity "to give rise to concern that violations are occurring and that future measures might amount to further violations of the obligations' contained in the ICESCR".68

On the basis of the incoming information from the csos, the Committee requested the Government of the Philippines to respond to the issues, which it did in the following year. ${ }^{69}$ Notably, the action has prevented a planned forced eviction of 200,000 families, which if undertaken without adequate resettlement sites being made available would be incompatible with the State's commitment to the ICESR. ${ }^{70}$ The Committee also recommended that the Government should ensure that forced evictions are not carried out except in truly exceptional circumstances, following consideration of all possible alternatives and in full respect of the rights of all persons affected. ${ }^{71}$

The case illustrates the achievement of participation in the reporting procedure of the United Nations system. The whole process was initiated on the basis of the report received from the csos, which as recalled are one of the channels to exercise participation. Furthermore, it should also be recorded that the process has successfully prevented a potentially development hazard occurred in breach of the state's obligation under the ICESCR. Of more importance is that the Committee was not simply intent on making a declaration of incompatibility, but was concerned with forestalling potential future violations. ${ }^{72}$

67 M. Craven, The International Covenant on Economic, Social and Cultural Rights A Perspective on its Development (Oxford: Clarendon Press, 1995), 466.

68 UN doc. E/1994/23, Report of the Committee on Economic, Social and Cultural Rights, paragraph 374 .

69 M. Craven, "The International", 466.

70 The Committee has received information from a variety of sources indicating that largescale forced evictions occur frequently and are estimated to have affected hundreds of thousands of persons since the ratification of the Covenant by the Philippines. One figure presented to the Committee asserted that some 15,000 families were forcibly evicted between June 1992 and August 1994. The scale of forced evictions and the manner in which they are carried out are of concern to the Committee. The Government itself acknowledges that planned forced evictions may affect up to 200,00o families, and that the Government has identified only 150,000 relocation sites. If these estimates are correct a very significant number of persons currently threatened with eviction will not receive adequate resettlement. Such a situation would not be compatible with respect for the right to housing. UN doc. E/C.12/1995/7, Concluding observations of the Committee on Economic, Social and Cultural Rights: Philippines, Paragraph 16.

$71 \quad$ Ibid., 31.

72 M. Craven, The International, 467 , noted that there is nothing in the Covenant or in the ECOSOC's resolutions that specifically authorizes the introduction of such a procedure, 
At the national level, another example of a case of the preventive function is also coming from the Philippines. In the case of Oposa et al. v. Fulgencio S. Factoran, Jr. et al. from the Supreme Court of the Phillipines in 1993, a class action was registered seeking the cancellation and non-issuance of timber licence agreements which allegedly infringed, inter alia, the constitutional right to a balanced and healthful ecology. ${ }^{73}$

An action was filed by several minors represented by their parents against the Department of Environment and Natural Resources to cancel existing timber license agreements in the country and to stop issuance of new ones. It was claimed that the resultant deforestation and damage to the environment violated their constitutional rights to a balanced and healthful ecology and to health, regulated in the Sections 16 and 15, Article II of the Constitution of the Philippines. The petitioners asserted that they represented others of their generation as well as generations yet unborn.

Finding for the petitioners, the Court stated that even though the right to a balanced and healthy ecology is under the Declaration of Principles and State Policies of the Constitution and not under the Bill of Rights, it does not follow that it is less important than any of the rights enumerated in the latter. The right is linked to the constitutional right to health, is "fundamental", "constitutionalized", "self-executing" and "judicially enforceable". It imposes the correlative duty to refrain from impairing the environment. ${ }^{74}$

From these two cases, it can be observed how participation, through a form of submitted reports, petitions or class actions submitted to the judiciary systems can secure the entitlement positions of the right-holders to protect them against potentially hazardous development policies. The implementation of participation in these cases is exercised from below with the aim of preventing hazardous impacts of development processes. Providentially, an enabling environment exists; legal complaint mechanisms are available to ensure that

but then again, there is nothing that prohibits it. The Committee's creative interpretation of its mandate seems constrained only by the extent to which it may potentially alienate states from the process as a whole.

73 The other claims of this class action are violations of environmental law; judicial review and the political question doctrine; inter-generational responsibility; Remedial law: cause of action and standing; directive principles; negative obligation on state. Oposa et al. v. Fulgencio S. Factoran, Jr. et al. (G.R. No. 101083), Supreme Court of the Philippines, July 30, 1993.

74 The court stated that the petitioners were able to file a class suit both for others of their generation and for succeeding generations as "the minors' assertion of their right to a sound environment constitutes, at the same time, the performance of their obligation to ensure the protection of that right for the generations to come". Ibid. 
the report, class action or petition is addressed justly. Moreover, they demonstrate accountable to force the potential perpetrators, in this case the State, to enforce their decisions made therefrom.

The preventive function to the entitlement to participation in combating development hazards is not only possible to be performed in the judicial domains. In the case of a UNICEF development program in Uganda for example, participation, implemented as a part of the UNICEF's human rights based approach program of 2003, had increased the awareness of the people to the subject, resulting in the increase of the immunization coverage of about $80 \%$. Children and young people were observed as active actors in claiming this entitlement. ${ }^{75}$ Exercising the entitlement of participation has led to a growing awareness of the duty-bearers, which was reflected in the development of partnership, and has prevented unnecessary rise of morbidity amongst children. ${ }^{76}$

\subsubsection{Remedial Function}

The remedial function of the entitlement to participation refers to a situation whereby participation is exercised with the objective to claim compensation or retribution in a situation of development hazard.

At the regional level, one case to illustrate this is again the Oil Case in Nigeria at the African Commission of Human and Peoples Rights in 2001. In the communication submitted by the Social and Economic Rights Actions Centre and the Centre for Economic Social Rights, the complainants alleged that the military government of Nigeria has been directly involved in oil production through the State oil company, the Nigerian National Petroleum Company (NNPC), the majority shareholder in a consortium with Shell Petroleum Development Corporation (SPDC), and that these operations had caused environmental degradation and health problems resulting from the contamination of the environment among the Ogoni People. ${ }^{77}$

Responding to the complaint, the Commission recalled the duty of the government to protect its citizens, not only through appropriate legislation and

75 U. Jonsson. "A Human Rights-based Approach to Programming", in Reinventing Development? Translating Rights-based Approaches from Theory into Practice, eds. P. Gready and J. Ensor (London: Zed Books, 2004), 58.

76 The program had been noted to be successful those areas, but it had been difficult to expand the programme due to resource constraints both economic and human resources. Ibid., 59 .

77 The Social and Economic rights Action Centre and the Centre for Economic and Social Rights v Nigeria, African Commission on Human Rights Communication No. 155/96, Fifteenth Activity Report 1999-200o, Annex V. M. Sepulveda et al., Universal and Regional Human Rights Protection: Cases and Commentaries 295 (2004). 
effective enforcement, but also by protecting them from damaging acts that may be perpetrated by private parties. This duty calls for positive action on the part of governments in fulfilling their obligations under human rights instruments. The Commission stated that violations occurred in the case of the right to enjoy the best attainable state of physical and mental health in Article 16 (1) and the right to general satisfactory environment favourable to development in Article 16 (3) of the African Charter. Therefore the Commission ruled that the Nigerian Government had to ensure adequate compensation to victims of the human rights violations, including relief and resettlement assistance to victims of government sponsored raids, and undertaking a comprehensive cleanup of lands and rivers damaged by oil operations.

At the national level, the Grootboom case in South Africa demonstrates the potentiality of participation to seek remedy by means of judiciary mechanism. In the Grootboom case, a community of squatters, evicted from an informal settlement in Wallacedene had set up minimal shelters, made of plastic and other materials at a sports centre adjacent to Wallacedene community centre, which lacked basic sanitation and electricity. The group brought an action against their eviction without provision of compensatory housing under sections 26 (the right of access to adequate housing) and 28 (children's right to basic shelter) of the South African Constitution against various levels of government.

The High Court found that the respondents had taken reasonable measures within available resources to achieve the progressive realisation of the right to have access to adequate housing - as required by Article 26 of the Constitution. ${ }^{78}$ However, because the right of children to shelter in Article 28 was not subject to available resources, the High Court held that the applicants were entitled to be provided with basic shelter.

On appeal to the Constitutional Court, the Court found no violation of Article 28, and instead a violation of the right to adequate housing in Article 26. The Court held that Article 26 obliges the state to devise and implement a coherent, co-ordinated housing programme and that in failing to provide for those in most desperate need the government had failed to take reasonable measures to progressively realise the right to housing. The case ended in a mandatory court order commanding the South African government to secure

78 The Judge ruled that that a rational housing programme has been initiated at all levels of government and that such programme has been designed to solve a pressing problem in the context of the scarce financial resources. See Grootboom case, Government of the Republic of South Africa. \& Ors v Grootboom \& Ors 2000, The High Court of South Africa, Case No. 6826/99. 
alternative shelter for Irene Grootboom and the 899 other poor and vulnerable individuals they had removed from their squatter compound. The South African Human Rights Commission agreed to monitor and if necessary report on the governments' implementation of this order.

The decision had a major impact on housing policy in South Africa. ${ }^{79}$ Most municipalities put in place a "Grootboom allocation" in their budgets to address the needs of those in desperate need. ${ }^{80}$ The applicants were provided with basic amenities as a result of a settlement reached prior to the hearing of the case by the Constitutional Court, but the results of the decision for the community have been disappointing. Further legal action was taken to enforce the remedy against the local government. Nevertheless, even after more than five years, this order has only been marginally implemented.

From the two examples, it can observed that although participation through the legal procedure can certainly help in acquiring remedies for development hazards, its implementation still depends on the good will of the dutybearers. The human rights struggle does not stop once a remedy is ordered by the legal authority, but it should be accompanied with concrete implementation taken by the duty-bearers. Furthermore, the right-holders and other supporting actors are required to continue to exercise the entitlement to participation, by for example monitoring the execution of the court's orders in providing the compensation and retribution.

\section{Concluding Remarks}

Thirty years after the Declaration on the Right to Development of 1986 was adopted by the United Nations General Assembly, the right to development has progressively gained more attention in international law and has resulted in guidelines towards enforcement at practical levels. At the United Nations' level, the right to development enjoys a high status of consensus. Development is understood as part of human rights' struggles and the importance of the

79 The case has also impact in the process of law making based on ethical and political principles of human rights. For further analyses on this see: B. de Gaay Fortman, "Adventurous Judgement, A Comparative Exploration into Human Rights as a Moral-Political Force in Judicial Law Review". Utrecht Law Review 2 (2006): 36.

8o Other cases where the judges also refer to the Grootboom case are Minister of Public Works \& Ors. V. Kyalami Ridge Environmental Association \& Ors of the Constitutional Court of South Africa of 2001 and Port Elizabeth Municipality v. Various Occupiers of the Constitutional Court of South Africa of 2004. 
right to development has been widely acknowledged. Yet, current applications of the right to development at the States' and international levels have not yet delivered substantive changes at the national and local levels. The common criticism that the right to development is a confusing compilation of ideas brings into question its progressive realisation.

It has been explained although development has the general connotation of a structural improvement of people's well-being, yet in practice, it often affects the entitlement positions of those who have to sustain their daily livelihoods in a negative way. This happens particularly when decisions on development are taken by governments without any prior consultation, let alone participation of stakeholders. The point is that such policies are often decided not with the aim of eradicating social injustices or improving the living conditions of people, but solely on the basis of macro priorities, viz. economic growth and productivity or macro-economic and political stability. As a result they are likely to exert detrimental effects on people. Hence, instead of being the beneficiaries, people at the grassroots level actually become victims. It is in such contexts that we have considered development as being a hazard.

The right to development should be able to deal with this particular reality. As the right to development takes its starting point in the need for consistent implementation of all human rights in all processes of development, there is good reason to take it as a starting point in an analysis of the complex interface between development practices and human rights standards and procedures. The right to development should be seen as to have the concern of how development is carried out that encompasses a critical examination of the overall development process.

In this article regard has been made in relation to the entitlements to fair distribution of benefits and participation. The entitlement to a fair distribution of benefits would seem to imply that a violation occurs when development does not deliver benefits for those affected or, perversely, harms the right-holders. The entitlement to participation entails that the process of development requires the involvement of the stakeholders. The United Nations General Assembly Declaration on the Right to Development proposes two distinct options: firstly, by stipulating a participatory environment process that is stimulated by the State, and secondly, by asserting actions from below, emphasising a participatory activity that is, first and foremost, at the initiative of the right-holders themselves.

The entitlement to fair distribution of benefits is the basic argument of establishing a violation-based approach to the right development as it indirectly creates an obligation not to cause any harm in development processes. Against this analytical framework, the right to development as a human right 
provides the obligation to combat that any harmful conduct in development. In this article it has been argued that the implementation of the right to development should be advanced through efforts that specifically address the losses and sufferings experienced by victims of development projects, policies and programs. Connected to those particular inferences, establishing a violationbased approach would also require the entitlement to participation, which allows the right to development to be employed to avoid and combat the phenomenon of development hazards. Based on these two entitlements guaranteed in the Declaration, the right to development is compelling legal principle for addressing development hazards. 